\title{
BECKER'S ECONOMIC THEORY IN THE GENESIS OF THE INSTITUTE OF ECONOMIC POWER IN MODERN UKRAINE
}

\author{
Elena Moiseenko \\ Department of economics and law \\ Kharkiv Humanities University "People's Ukrainian Academy» \\ 27 Lermontovskaya str., Kharkiv, Ukraine, 61000 \\ lexelit@gmail.com
}

\begin{abstract}
The article analyzes problems of power in general and economic power in particular, appeared on the background of extreme conditions of the development of social relations in modern Ukraine, caused by radical transformation of social and state institutions. The author tried to consider the distribution of power authorities between main influence groups under conditions of globalization from the point of view of G. S. Becker's theory, who stated that “... the economic approach provides maximizing behavior in more expressed form and wider approach, than other ones..." According to the author, the use of the economic approach at analyzing the genesis of the power institute in modern Ukraine is universal, because it is based on main economic paradigms of human behavior acceptable, wholesale, imputed, shade and so on prices; repeated and reiterated, important and insignificant decisions; emotionally loaded and neutral aims; behavior of nouveaux riches, ill, medics, businessmen and workers, professors and students, law-abiding citizens and criminals. The application area of the economic approach, understood in such a way, is so wide that it includes the subject of economic science. The importance of studying power problems grows, when the researcher addresses to the concrete society, in which on the background on general processes of globalization, build-up of tendencies of openness of national economies, typical for the whole European civilization, radical changes of social and state institutions take place, and as a result extreme conditions of social development and human existence appear. Ukraine found itself in such conditions in last years, so it causes a necessity to consider possibilities of the effective distribution of power between main economic agents under conditions of global economy from new positions. Problems of the Ukrainian state also actualize the analysis of the mechanism of economic power to the great extent, in particular, in concerns the economic decay, complete dependence of Ukraine on external markets and influences, collapse of the "two-vector" policy, declared by the Ukrainian authorities during the years of independence - this all gives grounds for rethinking the role of power in the open economic system, which part is the native economy. tion, policy.

Keywords: economics, economic approach, maximization, markets, power, economic power, pressure groups, corrup-
\end{abstract}

\section{Introduction}

In whole the problem of economic power is not new. The attention to the power phenomenon is explained by the fact that power is able to consolidate social and state institutions in a united political form, and also has a possibility to overcome crisis manifestations in the socio-economic system. The main complication is that the economic theory hasn't elaborated its own concept of power: works, devoted to the systematic study of the notion "economic power" are practically absent. Scientists' address to separate aspects of this question (forced submission and authority [1], conception of power in the paradigm of economic analysis [2], power as a phenomenon of the economic life of the society [3], power relations in the economic system [4, 5], power as a dominating problem of economics [6]) doesn't exclude a necessity of the further complex investigation: today a series of principal problems, neglected by scientists till now, concerning, in first turn, strengthening of the level of participation of a state in the process of socio-economic development of the system under conditions of open economy that, in its turn, results in a necessity to redistribute power authorities between main economic agents appears.

\section{Aim of research}

The aim of the work is to elucidate main determinants of economic power in Ukraine using G. S. Becker's economic theory, for increasing the competitiveness of the state as a subject of open economy under conditions of globalization of the international environment. 


\section{Methods of research}

The work applies: general dialectic method of scientific cognition of reality and also special methods (historical-legal - the historical excursus allowed to determine preconditions of the development of the legal component of economic power in Ukraine, comparative method allowed to reveal general tendencies of the genesis of economic power and economic theory, statistical analysis of the activity of economic agents, demonstrated its criminal-corruption directionality, system-structural method gave a possibility to classify considered pressure groups by their economic effectiveness, the modeling method was used for graphic realization of a series of structured factors, main conclusions were made using the method of generalization) and other. They all were applied in mutual connection that favored the comprehensiveness, completeness and objectiveness of a scientific search, concreteness, relevance and coordination of conclusions, formulated in the article.

\section{Results and discussion}

The power mechanism (we talk about all types of power competences) in modern realities of Ukrainian state is mainly not a result but the initial cause of main problems of Ukraine - economic decay, absolute dependence of Ukraine on external markets and retortions, collapse of the "two-vector" policy, declared by power structures during many years of independence.

This all gives grounds for rethinking the role of power in the open economic system, which part is the native economic paradigm.

For reviewing base tendencies of the development of power economy, let's address to the neoinstitutional theory of G. S. Becker with a rather wide structure $[7,8]$.

Realities of our state are such that the definition of "power" is in most cases replaceable by the notion "political group".

In its turn, a political group, according to the economic approach, is defined as one of pressure groups, which activity aim is the use of political preferences for attaining the maximal welfare of its participants.

The activity of such groups takes place on the background of the continuously developing competition for the most power, both political and economic.

In the process of fighting for economic power there are no absolute winners and absolute losers - any outsider in the run for power can intensify its influence and decrease financial and material expenditures $[9,11]$.

Groups interact with each other, transforming their costs, spent for the political pressure, in the economic influence and access to economic resources.

Such competitive process takes place according to the set procedure and never deviates from accepted maxims, signed in constitutions and/or other normative legal acts with the higher juridical force.

None state during the whole history - no tyrannies, no monarchies, no partocracies, no democracies - avoided a pressure from groups with the economic influence that strived for using their power for maximizing incomes [10].

It is worth to remind the early Greek (or older) tyranny, existed just to the moment of divergence of financial interests of a lord Pisistratus and aristocratic families (as to olive plantations). And Taleyran as a protégé and spokesman of material hopes of greatest representatives of French bourgeoisie hammered a last peg in the cover of the coffin of Napoleon's empire. The destruction of a cargo of tea, belonged to the English Ost-Indian company in the Boston harbor that turned out just an act of pressure on the Britain government by the group of American colonists, was the beginning of the American revolution - all started because of divergence of trade tariffs for English and American trade merchants, which desire to raise welfare in the own group resulted in creation of the new state. There are a lot of such examples.

G. S. Becker thought that any power action like any production process is prompted by identical economic motives [7]:

- minimization of transaction costs - it is a most important aim and result of functioning of any economic structure, including the power one that being a long-term institutional form of econom- 
ic relations not only needs information resources, but provides the decrease of costs that could appear at organizing the same relations in another way and not as a legal enterprise just by its existence;

- creation of a product or a service or an idea, understood by certain potential consumers as new ones and so on;

- creation of "power bodies" - a striving of organizers for regularizing functioning of their economic structures for minimizing transaction costs results in formation of "economic power bodies", able to be responsible for the further control and management of different market segments, to realize a mission of the "shade" court and to set contacts with the environment;

- consolidation of independent producers in "firms" with constructing "overfirm associations" above them for providing, at first, realization of share agreements between private pressure groups and ones with economic power, at second, agreements between pressure groups and support ones.

Fig. 1 presents the scheme of "agreements - contracts" of a community with economic power that specializes in selling goods and giving services.

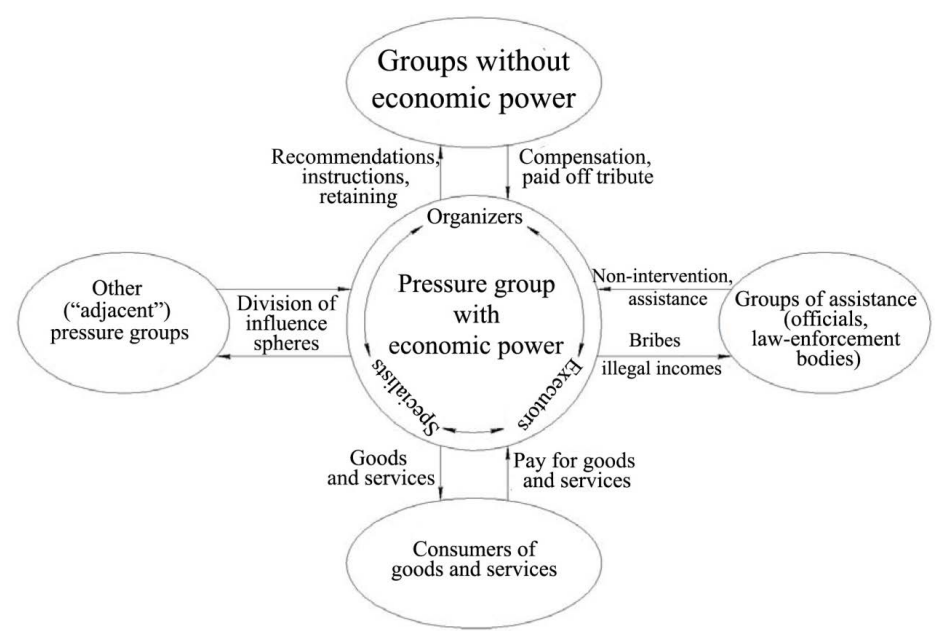

Fig. 1. System of contracts of pressure group with real economic power

It is worth noting that groups with real economic power not only redistribute incomes by political means, but actively form markets, both legal and shade ones [9].

It was already noted long ago that different shade markets - ones of prohibited goods and services - are characterized with different degrees of organization and monopolization.

For example, illegal financial transactions are controlled by organized criminals more than the process of "cashing", and among illegal financial markets, currency ones are more monopolized, whereas ones of underground bank systems - much weaker or not at all (depending on the typology of a shade bank system) [12].

It can be explained by the fact that in the shade activity and in legal business it is expedient to monopolize only branches with the real monopolistic motivation: spread of the diapason, rare raw material resources, expensive production means and so on.

Really, "...forming an organization and giving a certain authority ("entrepreneur") a right for directing resources, it is possible to decrease some market costs..." [12].

The wider spread of the shade economic activity of a power structure, the more expensive counteraction of competing groups and law-enforcement bodies is.

That is why the wide-ranging stationary shade activity needs mutually beneficial private contracts, from the one side, between pressure groups, from another one, agents of economic power with officials and law-enforcement bodies.

Pressure groups - owners of real economic power - divide influence spheres (territories, types of activity), agreeing about cooperation rules and competition.

Corrupted officials and order guardians receive a permanent cash allowance (or other useful services, for example, help in controlling their unorganized fellows), being obliged not to demonstrate the "excessive official zeal" [13]. 
It must not be forgotten, that creation of a pressure group of any level decreases expenditures for agreements and bribes for each its participant, because the number of partners in a bargain increases (heads of pressure groups act on behalf of all their members).

Having an economic advantage as a priority, subjects of economic power usually minimize their actions, causing an abrupt rejection and negative social reaction (growth of prices, threats, lobbying) and retain their manifestations from other less influential pressure groups themselves because the opposite is not just profitable for them.

Average citizens get a possibility to purchase permitted, prohibited and deficit services and goods, many of them find a job in representation agencies of economic power.

"Spontaneous" or uncontrolled groups are also included in the system of illegal contracts, acting as "subcontractors" of groups with economic power.

The economic activity at the "territory" of subjects of economic power without permission is extremely dangerous - disturbers of financial rights risk losing much without bureaucratic delays and excessive humanism.

But "spontaneous agents" can use consulting services of pressure groups that allows to decrease costs of their activity [14].

And as apotheosis of organization-production arrangements as a result of creating a group with economic power, acting in both legitimate and shade sphere, there is formed an atmosphere of some kind of "social consensus", inherent to most economic systems.

Participants of this cluster structure of private contracts get a certain profit (both real and illusory). Really, although "rules of game" are observed, economic power is not so evident and is not comprehended by the society as a social problem.

Economic power is developed not so quantitatively and "componently", but financially and "profitably" and is in the close interaction with different branches of the society.

Despite the fact that subjects of economic power develop their activity independently, meet seldom, have different types of expression and dissimilar consumers, they are inseparably connected by common aims and forms of realization.

At the same time economic power is a zone of crossing interests of pressure groups, often including the organized criminality, corrupted representatives of power structures and so on.

The difficultness of revealing facts of corruption and other official crimes, connected with economic power is undisputable, because an official status of functionaries, who commit them, creates essential obstacles for law-enforcement bodies in detecting corruption crimes of this directionality.

Often the activity of groups with economic power is realized, encouraged and protected (hidden) by persons with essential political and administrative resources that they (corrupted persons) use for defending from law-enforcement bodies.

It must be also taken into account that corruption crimes are often committed by pressure groups that helps each other, using their official status.

This all influences the difficultness of using the operative information about these crimes that often remains unprovable that extremely complicates the investigation of such crimes.

It also increases scales of latency of the activity of power economic structures.

And latency of corruption results in impunity and self-determination of not only corruption but also illegal activity of representatives of pressure groups with economic power, allowing criminals to avoid the penal persecution (Fig. 2).

It forms the steady legal nihilism in the population as to economic power, alienation and distrust to law-enforcement bodies.

At the same time there forms and intensifies an opinion about a necessity of a bribe as a means of attaining an aim, solution of a problem (even if ways of its legal solution exist), perverted sense of justice, moral degradation.

The economic success of a pressure group is determined not by absolute determinants of its effectiveness (for example, absolute ability to control the price behavior of any market), but relative - ratio with determinants of the effectiveness of other groups $[15,16]$. 


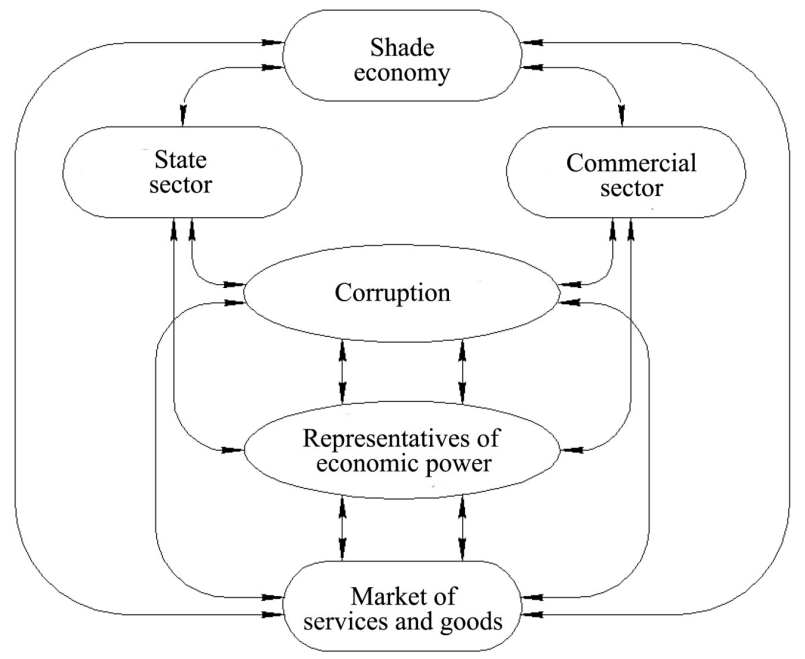

Fig. 2. Scheme of relations between representatives of pressure groups with economic power and different elements of shade economy

\section{Conclusions}

1. Thus, we have considered the formation stages of the economic power system, which functioning is supported by corruption relations, formed in different spheres that is vertically and horizontally, between officials and state workers of different levels, relative to Becker's economic theory.

2. It allows to mask the criminal activity and to stimulate its prolongation effectively.

3. So, (in the complete accordance with Becker's economic theory), the system of economic power must be considered as a cluster structure of local-monopolistic pressure groups, each moment suffering from the uninterrupted rigid competition for the political and economic influence.

\section{References}

[1] Bardhan, P. (1991). On the concept of power in economics. Economics and Politics, 3 (3), 265277. doi: http://doi.org/10.1111/j.1468-0343.1991.tb00050.x

[2] Salamon, L., Hems, L., Chinnock, K. (2000). The Nonprofit Sector: For What and for Whom? Working Papers of the Johns Hopkins Comparative Nonprofit Sector Project, 37, 7-9.

[3] Palermo, G. (2000). Economic Power and the Firm in New Institutional Economics: Two Conflicting Problems. Journal of Economic Issues, 34 (3), 573-601. doi: http://doi.org/10.1080/00213624.2000.11506295

[4] Otto, D. (1996). Nongovernmental Organizations in the United Nations System: The Emerging Role of International Civil Society. Human Rights Quarterly, 18(1), 107-141. doi: http://doi.org/10.1353/hrq.1996.0009

[5] Pryor, F. L. (2005). Market economic systems. Journal of Comparative Economics, 33 (1), 2546. doi: http://doi.org/10.1016/j.jce.2004.12.004

[6] Albert, H.; Rothschild, K. (Ed.) (1971). The Neglect of Sociology in Economic Science. Power in Economics. Harmondworth: Penguin books, 21-35.

[7] Becker, G. S., Kominers, S. D., Murphy, K. M., \& Spenkuch, Jj. L. (2015). A Theory of Intergenerational Mobility. SSRN Electronic Journal. doi: http://doi.org/10.2139/ssrn.2652891

[8] Khrestomatiya po istorii ekonomicheskoy mysli (2010). Minsk: BelGU, 3069.

[9] Ituell, Dzh., Milgeyt, M., N'yumen, P. (2008). Nevidimaya ruka rynka. Moscow: Izd dom GU-VSHE, 388.

[10] Shastitko, A. E. (1998). Neoinstitutsional'naya ekonomicheskaya teoriya. Moscow.

[11] Wicksell, K. (2012). Lectures on political economy. Volume 1. General theory. Ludwig von Mises Institute.

[12] Zhubrin, R. V. (2011). Bor'ba s legalizatsiey prestupnykh dokhodov. Teoreticheskie i prakticheskie aspekty. Moscow: Volters Kluver, 488.

[13] Zhilina, I. Yu., Ivanova, N. N. (1998). Ekonomika korruptsii. Sotsial'no-ekonomicheskie aspekty korruptsii. Moscow, 30-62.

[14] Kupreshchenko, N. P. (2013). Tenevaya ekonomika. Moscow: YUNITI-DANA: Zakon i pravo, 199.

[15] Pakhomov, V. R. (2010). Vzyatochnichestvo i korruptsiya v deyatel'nosti prestupnykh struktur. Moscow: Laboratoriya knigi, god, 98.

[16] Kirilenko, V. P., Dronov, R. V. (2012). Korruptsiya i ee svyaz' s tenevoy ekonomikoy. Upravlencheskoe konsul'tirovanie, 3 (47), 28-36. 